\title{
A Survey on Monitoring Water Quality by Aid of IoT
}

\author{
Ali Hadi Abdulwahid ${ }^{1 *}$, Muwaffaq Jameel Salih ${ }^{2}$ \\ \{dr.alhajjiali@stu.edu.iq ${ }^{1}$, muwaffaq.jameel@stu.edu.iq $\left.{ }^{2}\right\}$ \\ Southern Technical University/Engineering Technical College /Basra \\ Southern Technical University/Faculty of Graduate Studies/ Basra ${ }^{2}$
}

\begin{abstract}
The many types of environmental surveillance systems connected to water quality are covered in this study. To explain each water monitoring system with diverse characteristics, many parameters are considered. Over the last years, the technology features of several approach methodologies linked to water quality monitoring, as well as their installation with the IoT component, have been studied. In this study, the process of various approaches to the technologies employed will be critically evaluated, as well as which techniques are focused on which parameters.
\end{abstract}

Keywords: Water, quality, Monitoring, IoT.

\section{Introduction}

This Water quality monitoring system comprehension and execution is now a very significant side of today's society. Typical approaches are mostly utilized to collect results, such as chemical samples, physical situations, and biological facts [1][2]. The most basic methods for these parameters are condition monitoring, which includes understanding problems or risks to assess specific causes of dysfunction and evaluate pollution inputs, and problem investigation monitoring, which requires understanding problems or risks to determine specific causes of dysfunction and evaluate pollution inputs[3]. Another method for surveillance of water goodness is to use the Internet of Things (IoT), and this study concentrates on the IoT element of surveillance of water goodness. The following are the factors that are primarily considered for water quality monitoring and are defined by WHO as shown in table 1 . The rapid growth of industry, as well as a higher reliance on agricultural expansion, are two of the key causes of this problem[4]. Because of the non-uniform rainfall distribution, the situation might occasionally become worse. Droughts and floods, as well as insufficient knowledge and understanding among people, are other origins of polluted water. According to the World Water Assessment Program, almost two million tons of human waste are discharged into the water each day.

The different types of contaminants, many of which are human-made, make ensuring the safety of water a difficult task. Excessive use of natural resources is the primary cause of water pollution issues. Monitoring water quality continuously is an important aspect of determining water quality since it is impossible to determine how frequently water quality is affected. 
Governments, communities, and corporations must now satisfy a variety of water quality objectives. As a result, a wide water quality monitoring system is often required.

This paper starts with giving Common chemical and physical water goodness parameters then in the next part a glance at the Internet Of Things (IoT) is given, after that The existing water monitoring systems are reviewed. Finally, there is the conclusion of the paper.

Table 1. IoT parameters of water quality monitoring

\begin{tabular}{|c|c|c|c|}
\hline \multirow{2}{*}{ Parameters } & \multirow{2}{*}{ Units } & \multicolumn{2}{|c|}{$\begin{array}{c}\text { Drinking water } \\
\text { IS: 10500 - 1991 }\end{array}$} \\
\cline { 3 - 4 } & & Desirable & Maximum \\
\hline Turbidity & $\mathrm{NTU}$ & 5 & 10 \\
\hline $\mathrm{pH}$ value & - & 6.5 to 8.5 & $\begin{array}{c}\text { No } \\
\text { relaxation }\end{array}$ \\
\hline $\begin{array}{c}\text { Total } \\
\text { hardness } \\
\text { (as CaCO3) }\end{array}$ & $\mathrm{mg} / \mathrm{l}$ & 300 & 600 \\
\hline Iron & $\mathrm{mg} / 1$ & 0.3 & 1 \\
\hline Chlorides & $\mathrm{mg} / \mathrm{l}$ & 250 & 1000 \\
\hline Calcium & $\mathrm{mg} / 1$ & 75 & 200 \\
\hline Copper & $\mathrm{mg} / 1$ & 0.05 & 1.5 \\
\hline Manganese & $\mathrm{mg} / 1$ & 0.1 & 0.3 \\
\hline Sulphate & $\mathrm{mg} / 1$ & 200 & 400 \\
\hline Nitrate & $\mathrm{mg} / \mathrm{l}$ & 50 & $\begin{array}{c}\text { No } \\
\text { relaxation }\end{array}$ \\
\hline
\end{tabular}

\section{Common Chemical and Physical Water Goodness Parameters}

A. pH: can be considered as a metric for determining how acidic or alkaline a liquid is. A $\mathrm{pH}$ of 7 is considered neutral, while $\mathrm{pH}$ values lower and above 7 are acidic and alkaline, correspondingly. A pH range of 6.0 to 9.0 is usually suggested for distribution systems.

B. Electrical conductivity: This parameter is a measurement of a liquid's ability to conduct electricity. The amount of conductive ions present in salt that is dissolved in liquid and other inorganic compounds is measured as conductivity. The higher the conductivity, the more salts are dissolved. The conductivity of drinkable water must be within 0 to $2500 \mathrm{~S} / \mathrm{cm}$.

C. Oxidation-reduction potential (ORP): The strength with which electrons are transported across different species in a liquid is measured by RP. This demonstrates water's ability to remove pollutants on its own. ORP measurements in healthy water are often very high. 
D. Turbidity: This is measured in nephelometric turbidity units (NTU) and represents the density of suspended and colloidal particles in water. Turbidity of less than 1 NTU should be present in drinkable water.

\section{Internet Of Things (IoT)}

In numerous study domains, the IoT technique is used to track, acquire, and analyze data from remote sites. Because of the increase in data volume, monitoring systems are now becoming important aspects of decision-making. Sensors based on the Internet of Things (IoT) might be utilized to offer precise water quality management. The Internet of Things (IoT) is a new type of environment in which practically every computer and piece of equipment we use are connected to a network. It may be combined to execute complex duties requiring a high level of intellect. For this information and interconnectivity, IoT systems include integrated sensors, actuators, processors, and transceivers. The Internet of Things (IoT) has a significant influence on almost every aspect of human existence. IoT uses the functionalities of Wireless Sensor Network (WSN) technology to convert daily living into a common phenomenon.

The IoT architecture is made up of various levels, as shown in Fig 1.

A. The sensing layer is the physical layer with sensors and an actuator.

B. The transport layer is the networking layer (Network Layer ). It delivers sensor readings from the physical layer to the layer of processing via networks different standards.

C. The processing layer sometimes referred to as the middleware layer, collects, analyzes, and manages vast volumes of data that come from the transport layer. It can accommodate and sustain a variety of resources. For big data analysis, it employs a variety of technologies, including databases, cloud storage, and modules.

D. As a result, the suggested system's purpose may be accomplished, and the application layer hosts an alarm system that can provide alert signals of water quality data to the decision-maker.

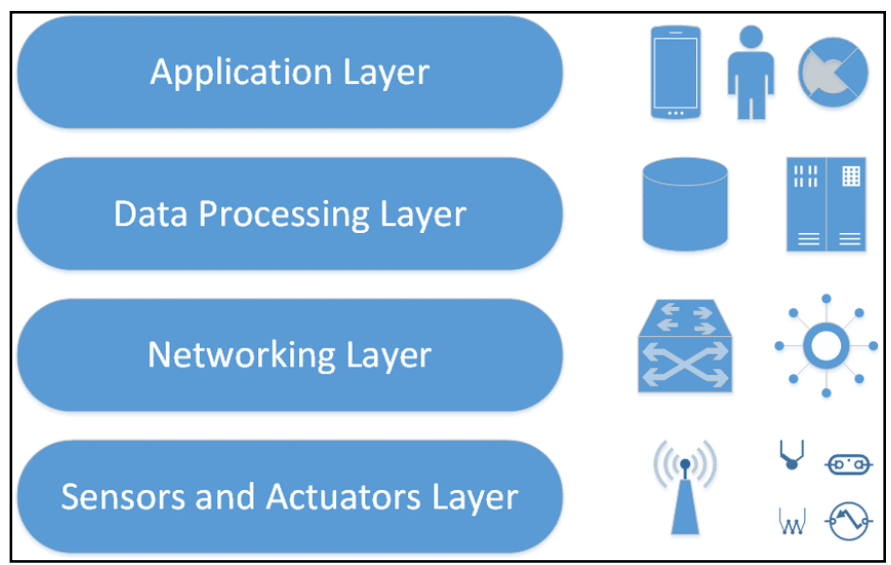

Fig.1. IoT architecture. 


\section{Water Monitoring Systems Review}

Ali Hadi Abdulwahid implemented a system to monitor the physical characteristics of water, such as temperature, $\mathrm{pH}$, turbidity, and electrical conductivity. Arduino board is used in this system as a core microcontroller. and ESP8266 module to transmit data to the Thingspeak server[1].

Abdallah Hammad, Talaat Salem, Mohie Omar designed and implemented IoT-based a lowcost Early Warning Framework (EWF) for water quality monitoring of the River Nile in realtime. The Prototype system is used to monitor three different water quality parameters $(\mathrm{pH}$, Turbidity, and Temperature). WiFi technology is used to send data to the cloud. The cost was the main aspect for designers. So the overall cost was in the acceptable range of about 197\$[5]. Brinda Das, P.C. Jain To assess water quality, the authors implemented a water quality control device to test water quality in real-time employing separate sensors (to sense the following parameters: electrical conductivity, $\mathrm{pH}$, and temperature). In this system, the ZigBee module sends data collected by the sensors wirelessly to the processing unit, and the GSM module transfers the data wirelessly from the microcontroller to the Smartphone/PC. In the event of anyone attempting to pollute the water body, the device even has proximity sensors to warn officials by sending a message to them through the GSM module[6].

K. Spandana and V.R. Seshagiri Rao assumed that the method proposed reduces the complexity and improves the efficiency by gathering water parameter data such as level of water, $\mathrm{Co}_{2}$ temperature, and $\mathrm{pH}$. The gathered information is stored in a database site that can be accessed from anywhere in the world. Using a Wi-Fi module, the interconnection between sensors and the work is accomplished wirelessly[4].

The system implemented by Sathish Pasika and Sai Teja Gandla utilizes ultrasonic, pH, turbidity, and DHT-11 sensors, a microcontroller device as the processing unit, and a single ESP8266 Wi-Fi module (NodeMCU) data transmission unit. All sensors are data collected and processed by the MCU and transferred to the ThingSpeak server by the ESP8266 (NodeMCU) Wi-Fi data connectivity module to the central server[3].

The system that was built by Luo Hongpin, Li Guanglin, Peng Weifeng, Song Jie, Bai Qiuwei, utilizes solar panels and lithium cells as an energy source. For the control of aquaculture water quality parameters, the YCS-2000 dissolved oxygen sensor, $\mathrm{pH}$ electrode, Pt1000 temperature sensor, and ammonia nitrogen sensor were used; the STM32F103 chip was used for data processing; the ZigBee and GPRS modules were used for data transfer to the remote monitoring center, where the data was processed and displayed. The device was attached to an aerator to automatically regulate the concentration of dissolved oxygen. This system was built by using of WeMos D1 mini and ( $\mathrm{pH}$, turbidity, temperature, and ultrasonic) sensors [6].

The research team consists of Abdul Rauf Memon, Saadia Kulsoom Memon, Abdul Aziz Memon, and Tayab Din Memon implement a framework. WeMos D1 mini is an Arduino-like board for transmitting sensor information over the internet with built-in Wi-Fi capability. For water quality data collection, internet data transfer, reporting, documentation, and analysis, the overall experimental setup was developed and tested. It is experimentally noticed that it takes less than a minute for the machine to change its values[7].

The sensor data are obtained by an ATmega32U4 microcontroller in this device proposed by Nansong Wuand and Muhammad Khan transmitted to a LoRa transceiver module. The 915 MHz frequency band MicrochipRN2903 LoRa transceiver communicates with the LoRa gateway, which can either be linked to the backbone Internet through WiFi or a wired network. Then the LoRa gateway forwards the information to the TTN cloud[8].

Md. Mahbubur Rahman, Chinmay Bapery, Mohammad Jamal Hossain, Zahid Hassan, G.M. Jamil Hossain, Md. Muzahidul Islam. Concentrate on multiple parameters. Like pH, turbidity, 
temperature, salinity, dissolved oxygen. Data from analog sensors is translated to digital data known as analog to digital converter(ADC). This information is processed through Arduino. The interpreted data is then sent to NodeMCU with Arduino and NodeMCU serial communications. Processed data parameters are then sent to the real-time Firebase servers[9]. The system proposed by Mourvika Shirode, Monika Adaling, Jyoti Biradar, Trupti Mate utilize conductivity, $\mathrm{pH}$, turbidity, and temperature sensors, a microcontroller as a processing module, and the four sensors collect data in analog signals type. The ADC generates the digital format of these signals. Via a WiFi module, these digital data are sent to the processing unit (the microcontroller). The microcontroller processes analyze and further communicates the digital information through the $\mathrm{WiFi}$ module, which transfers the water quality parameter information to the mobile smartphone or personal computer, which is also displayed on the microcontroller's LCD[10].

Sivasankari G.G, Bineet Kumar Jha, Venugopal K.R. design device operate on the Cloud-based Ubidots network for data integration and dashboard integration have been suggested. The device has several sensors stored within the water tank. Using ZigBee/Wi-Fi technology, these sensors are attached to the microcontroller. To read the outcome, the microcontroller is linked directly to the $\mathrm{LCD}[11]$.

Table 2. A comparison of suggested node design for water quality surveillance systems.

\begin{tabular}{|c|c|c|c|c|c|c|}
\hline No & Author(s) & $\begin{array}{c}\text { Water } \\
\text { Parameters }\end{array}$ & Controller & Communications & $\begin{array}{c}\text { IoT } \\
\text { Platform }\end{array}$ & Power Supply \\
\hline 1 & $\begin{array}{c}\text { Ali Hadi } \\
\text { Abdulwahid }\end{array}$ & $\begin{array}{c}\text { Temperature } \\
\text { pH } \\
\text { turbidity } \\
\text { conductivity }\end{array}$ & Arduino & WiFi & $\begin{array}{c}\text { ThingSpe } \\
\text { ak }\end{array}$ & not specified \\
\hline 2 & $\begin{array}{c}\text { Noha Kamal } \\
\text { Abdallah } \\
\text { Hammad } \\
\text { Talaat Salem } \\
\text { Mohie Omar }\end{array}$ & $\begin{array}{c}\mathrm{pH} \\
\text { Turbidity } \\
\text { Temperature }\end{array}$ & $\begin{array}{c}\text { Raspberry } \\
\text { Pi3 }\end{array}$ & WiFi & $\begin{array}{c}\text { not } \\
\text { specified }\end{array}$ & not specified \\
\hline 3 & $\begin{array}{l}\text { Brinda Das } \\
\text { P.C. Jain }\end{array}$ & $\begin{array}{c}\mathrm{pH} \\
\text { conductivity } \\
\text { temperature }\end{array}$ & LPC2138 & $\begin{array}{c}\text { Zigbee } \\
\text { GSM }\end{array}$ & $\begin{array}{c}\text { ThingSpe } \\
\text { ak }\end{array}$ & $\begin{array}{c}\text { power supply } \\
\text { adapter }\end{array}$ \\
\hline 4 & $\begin{array}{c}\text { K. Spandana } \\
\text { V.R. } \\
\text { Seshagiri } \\
\text { Rao }\end{array}$ & $\begin{array}{c}\mathrm{pH} \\
\text { level } \\
\mathrm{CO} 2\end{array}$ & ESP8266 & WI-FI & $\begin{array}{c}\text { not } \\
\text { specified }\end{array}$ & not specified \\
\hline 5 & $\begin{array}{l}\text { Sathish } \\
\text { Pasika } \\
\text { Sai Teja } \\
\text { Gandla }\end{array}$ & $\underset{\text { turbidity }}{\mathrm{pH}}$ & $\begin{array}{l}\text { Arduino } \\
\text { Mega }\end{array}$ & Wi-Fi & $\begin{array}{c}\text { ThingSpe } \\
\text { ak }\end{array}$ & $\begin{array}{c}\text { power supply } \\
\text { adapter }\end{array}$ \\
\hline 6 & $\begin{array}{c}\text { Luo } \\
\text { Hongpin } \\
\text { Li Guanglin } \\
\text { Peng } \\
\text { Weifeng } \\
\text { Song Jie } \\
\text { Bai Qiuwei } \\
\end{array}$ & $\begin{array}{c}\mathrm{pH} \\
\text { Ammonia } \\
\text { nitrogen, } \\
\text { temperature }\end{array}$ & GPRS & $\begin{array}{l}\text { Zigbee } \\
\text { GPRS }\end{array}$ & $\begin{array}{c}\text { not } \\
\text { specified }\end{array}$ & $\begin{array}{c}\text { battery } \\
\text { solar panels }\end{array}$ \\
\hline
\end{tabular}




\begin{tabular}{|c|c|c|c|c|c|c|}
\hline 7 & $\begin{array}{l}\text { Abdul Rauf } \\
\text { Memom }\end{array}$ & $\begin{array}{c}\mathrm{pH} \\
\text { turbidity } \\
\text { temperature } \\
\text { level }\end{array}$ & Arduino & Wi-Fi & $\begin{array}{c}\text { ThingSpe } \\
\text { ak }\end{array}$ & $\begin{array}{c}\text { power supply } \\
\text { adapter }\end{array}$ \\
\hline 8 & $\begin{array}{c}\text { Nansong } \\
\text { Wu, } \\
\text { Muhammad } \\
\text { Khan }\end{array}$ & $\begin{array}{c}\mathrm{pH} \\
\text { turbidity } \\
\mathrm{DO} \\
\text { temperature }\end{array}$ & $\begin{array}{c}\text { ATmega3 } \\
2 \mathrm{U} 4\end{array}$ & LoRa & TTN & not specified \\
\hline 9 & $\begin{array}{c}\text { Md. } \\
\text { Mahbubur } \\
\text { Rahman } \\
\text { Chinmay } \\
\text { Bapery } \\
\text { Mohammad } \\
\text { Jamal } \\
\text { Hossain, } \\
\text {, Zahid } \\
\text { Hassan } \\
\text { G.M. Jamil } \\
\text { Hossain } \\
\text { Md. } \\
\text { Muzahidul } \\
\text { Islam } \\
\end{array}$ & $\begin{array}{c}\mathrm{pH} \\
\text { Turbidity } \\
\text { Temperature } \\
\text { Dissolved } \\
\text { Oxygen } \\
\text { Salinity }\end{array}$ & Arduino & Wi-Fi & Firebase & not specified \\
\hline 10 & $\begin{array}{c}\text { Mourvika } \\
\text { Shirode } \\
\text { Monika } \\
\text { Adaling } \\
\text { Jyoti Biradar } \\
\text { Trupti Mate }\end{array}$ & $\begin{array}{c}\mathrm{pH} \\
\text { conductivity } \\
\text { turbidity } \\
\text { temperature }\end{array}$ & LPC2148 & Wi-Fi & $\begin{array}{c}\text { ThingSpe } \\
\text { ak }\end{array}$ & not specified \\
\hline 11 & $\begin{array}{c}\text { Bineet } \\
\text { Kumar Jha } \\
\text { Sivasankari } \\
\text { G.G } \\
\text { Venugopal } \\
\text { K.R. }\end{array}$ & $\begin{array}{c}\mathrm{pH} \\
\text { Turbidity } \\
\text { Temperature } \\
\text { Dissolved } \\
\text { Oxygen } \\
\text { Salinity }\end{array}$ & CC200 & Wi-Fi & Ubidotes & not specified \\
\hline
\end{tabular}

\section{Conclusion}

The study gives a summary of recent research on water monitoring methods that have been developed and are now being employed in the effective monitoring of water quality systems. In the context of IoT technology, each study has its specific value. The papers examined are all aimed at improving the water quality monitoring system and advancing it to a higher level in some way.

\section{References}

[1] A. H. Abdulwahid, "IoT Based Water Quality Monitoring System for Rural Areas," 9th Int. Conf. Renew. Energy Res. Appl. ICRERA 2020, pp. 279-282, 2020, doi: 
10.1109/ICRERA49962.2020.9242798.

[2] S. M. G. Nikkam and V. R. Pawar, "Analyzing water quality for industrial application under IoT environment," Int. Res. J. Eng. Technol., vol. 3, pp. 882-885, 2016.

[3] S. Pasika and S. T. Gandla, "Smart water quality monitoring system with cost-effective using IoT," Heliyon, vol. 6, no. 7, p. e04096, 2020.

[4] S. Shanthi, T. Gopi, and C. Vidhyesh, "IoT Based Water and Air Quality Monitoring System and Analysis," Int. J. Appl. Eng. Res., vol. 14, no. 6, pp. 1405-1409, 2019.

[5] N. Kamal, A. Hammad, T. Salem, and M. Omar, "EARLY WARNING AND WATER QUALITY, LOW-COST IOT BASED MONITORING SYSTEM,” JES. J. Eng. Sci., vol. 47, no. 6, pp. 795-806, 2019.

[6] L. Hongpin, L. Guanglin, P. Weifeng, S. Jie, and B. Qiuwei, "Real-time remote monitoring system for aquaculture water quality," Int. J. Agric. Biol. Eng., vol. 8, no. 6, pp. 136-143, 2015.

[7] A. R. Memon, S. K. Memon, A. A. Memon, and T. D. Memon, "IoT Based Water Quality Monitoring System for Safe Drinking Water in Pakistan," in 2020 3rd International Conference on Computing, Mathematics and Engineering Technologies (iCoMET), 2020, pp. 1-7.

[8] N. Wu and M. Khan, "LoRa-based Internet-of-Things: A Water Quality Monitoring System," in 2019 SoutheastCon, 2019, pp. 1-4.

[9] Z. Hassan, G. M. J. Hossain, and M. M. Islam, "Internet of Things (IoT) Based Water Quality Monitoring System,” Educ. Res., vol. 2, no. 4, pp. 168-180, 2020.

[10] M. Shirode, M. Adaling, J. Biradar, and T. Mate, "IOT based water quality monitoring system," Int. J. Sci. Res. Comput. Sci. Eng. Inf. Technol., vol. 3, no. 1, pp. 1423-1428, 2018.

[11] B. K. Jha, G. G. Sivasankari, and K. R. Venugopal, "Cloud-Based Smart Water Quality Monitoring System using IoT Sensors and Machine Learning," Int. J., vol. 9, no. 3, 2020. 